\title{
IMMIGRATION AND DISABILITY IN THE UNITED STATES AND CANADA
}

\section{Mark C. Weber*}

Disability arises from the dynamic between people's physical and mental conditions and the physical and attitudinal barriers in the environment. Applying this idea about disability to United States and Canadian immigration law draws attention to barriers to entry and eventual citizenship for individuals who have disabilities. Historically, North American law excluded many classes of immigrants, including those with intellectual disabilities, mental illness, physical defects, and conditions likely to cause dependency. Though exclusions for individuals likely to draw excessive public resources and those with communicable diseases still exist in Canada and the United States, in recent years the United States permitted legalization for severely disabled undocumented immigrants already in the country, and both countries abolished most exclusions from entry for immigrants with specific disabling conditions. Liberalization also occurred with regard to U.S. naturalization requirements.

Challenges continue, however. Under U.S. law, vast discretion remains with regard to the likely-public-charge exclusion, because consular officers abroad decide unilaterally whether to issue immigrant visas. Moreover, conduct related to mental disability, including petty criminality, can result in removal from the United States, and individuals with mental disabilities have only modest safeguards in removal proceedings. In Canada, families who have children with disabilities find themselves excluded from legal status because of supposed excessive demands on public resources, although an individual's disability may provide grounds for avoiding removal in certain cases. The relaxation of some immigration exclusions in Canada and the U.S. and of some U.S. requirements for citizenship illustrates a significant, though conspicuously incomplete, removal of disability-related barriers in North American law and society.

Le handicap découle de la dynamique entre les aptitudes physiques et mentales d'une personne et les obstacles physiques et comportementaux du milieu. L'application de cette perception du handicap au droit canadien et américain de l'immigration met en relief les obstacles à l'entrée et à l'obtention éventuelle de la citoyenneté pour les personnes handicapées. Dans le passé, le droit nordaméricain a exclu de nombreuses catégories d'immigrants, notamment les

* Vincent de Paul Professor of Law, DePaul University. Thanks to Salma Khalek, Rachel Milos, and Vaughn Bentley for their research assistance, and to Craig Mousin and Freya Kodar for their comments on early drafts of the paper. Special thanks to Ravi Malhotra, Michael Churgin, and Irene Bloemraad for sharing sources of research on immigration and disability, and to Laverne Jacobs for organizing the symposium. (C) 2015 Mark C. Weber. 
personnes ayant une déficience physique ou intellectuelle ou une maladie mentale et les personnes affligées d'une condition pouvant mener à la dépendance. Bien que des exclusions soient encore en vigueur au Canada et aux États-Unis dans le cas des personnes qui risquent d'entraîner un fardeau excessif pour le secteur public et des personnes souffrant d'une maladie transmissible, au cours des dernières années, les États-Unis ont autorisé des immigrants sans papier gravement handicapés qui étaient déjà au pays à légaliser leur situation; de plus, les deux pays ont aboli la plupart des exclusions relatives aux immigrants souffrant de certaines affections incapacitantes. Les exigences américaines en matière de naturalisation ont également été assouplies.

Cependant, de nombreuses difficultés subsistent. En droit américain, les autorités conservent un large pouvoir discrétionnaire en ce qui concerne l'exclusion des personnes susceptibles de représenter un fardeau pour le secteur public, car ce sont les agents consulaires en poste à l'étranger qui déterminent unilatéralement s'il y a lieu de délivrer ou non les visas d'immigrant. De plus, les comportements liés à une incapacité mentale, y compris les délits mineurs, peuvent entraîner le renvoi des États-Unis et les personnes souffrant d'une incapacité mentale ne disposent que de moyens de protection modestes dans les procédures de renvoi. Au Canada, les familles ayant des enfants handicapés sont exclues, en raison du fardeau excessif qu'elles risquent d'entraîner pour le secteur public, bien qu'il soit possible d'invoquer le handicap d'une personne pour éviter le renvoi dans certains cas. L'assouplissement de certaines règles d'exclusion au Canada et aux États-Unis ainsi que des exigences américaines en matière de citoyenneté témoigne d'un progrès important sur la voie de l'élimination des obstacles liés aux handicaps dans le droit et la société nordaméricains, mais il reste encore beaucoup à faire dans ce domaine.

\section{INTRODUCTION}

The foundational insight of contemporary disability studies is that physical and mental conditions do not necessarily disable. Disability instead arises from the dynamic between those conditions and the physical and attitudinal barriers in the human environment. ${ }^{1}$ Thus the need to use a wheelchair for mobility would not disable were it not for stairs, curbs, and attitudes towards wheelchair users that block an individual with paraplegia from full social participation. There are variations on, limits to, and criticisms of this "social model" of disability, but it remains central to current disability rights ideas. ${ }^{2}$ Applying a social model of disability to the law

1 Paula E Berg, "Ill/legal: Interrogating the Meaning and Function of the Category of Disability in Antidiscrimination Law" (1999) 18:1 Yale L \& Pol'y Rev 1 at 9; Mary Crossley, "The Disability Kaleidoscope" (1999) 74:3 Notre Dame L Rev 621 at 649-53.

2 Mark C Weber, "Disability Rights, Welfare Law" (2011) 32:6 Cardozo L Rev 2483 at 2485-87. For a comparison of an application of the social model of disability with a human rights approach in connection with income support, see ibid at 2526-30. 
bearing on immigration calls attention to barriers to legal entry into the United States and Canada and to the difficulties of eventually attaining citizenship for immigrants who have disabilities. As this article will demonstrate, these barriers are many, and they present serious challenges to would-be immigrants. Nevertheless, at least with regard to the underlying legal provisions that govern entry, there has been an evolution from attempted total exclusion of individuals with disabling conditions to increasing accommodation. Similarly, citizenship standards, at least in the United States, feature a number of disability accommodations. Some of the greatest obstacles pertain to negotiating the process of entry and avoiding removal.

This paper will discuss immigration and disability in the United States and Canada, applying insights of the disability rights movement. Part II will consider the history of disability-related exclusions from entry into the two countries. Part III will take up the recent relaxation of some grounds for exclusion and the continuing impact of others. Part IV considers two current issues in the law of immigration with regard to people with disabilities: disability-related hardship as a basis for stopping deportation from Canada of immigrants who would otherwise be subject to removal, and the risk of wrongful deportation from the United States of people whose mental impairments make it difficult for them to establish the right to remain. Part V will briefly consider recent developments affecting the acquisition of citizenship by immigrants with disabilities to the United States and Canada. The paper's conclusion evaluates the current state of the law in relation to the insights of the social model of disability and discusses the prospects for reforms of the law that the social model might suggest. The relaxation of various exclusions from immigration to North America and of some requirements for U.S. citizenship illustrates a significant, though conspicuously incomplete, removal of disability-related barriers in North American law and society.

\section{THE HISTORY OF DISABILITY AND IMMIGRATION IN NORTH AMERICA}

Exclusion on the basis of disability has a long history in both the United States and Canada. In the United States, disability and limits on entry into the national community have a disturbingly close connection. Professor Baynton writes:

Disability was a significant factor in the three great citizenship debates of the nineteenth and early twentieth centuries: women's suffrage, African American freedom and civil rights, and the restriction of immigration. When categories of citizenship were questioned, challenged or disrupted, disability was called on to clarify and define who deserved, and who was deservedly excluded from citizenship. ${ }^{3}$

Baynton concludes that the notion that disability disqualifies a person from being an American has rarely been challenged; rather, challenges are made to the assertion that members of the various groups denied full citizenship in fact have physical or mental disabilities, an approach

3 Douglas C Baynton, "Disability and the Justification of Inequality in American History" in Paul K Longmore \&

Lauri Umansky, eds, The New Disability History (New York: New York University Press, 2001) 33 at 33. 
that implicitly accepts the premise that disability is inconsistent with full membership in the community. ${ }^{4}$

The United States put exclusions into place for immigrants with mental disabilities and paupers near the end of the nineteenth century amid rampant fears about decline of the American population stock and the contemporaneous rise of Eugenics, a pseudo-science of optimal human breeding and the elimination of genetic inferiority. ${ }^{5}$ At roughly the same time, an identical fear of the disabled-other led to the institutionalization movement and additional widespread discriminatory practices, such as sterilization, exclusion from schools, and deprivation of voting rights. ${ }^{6}$

The link between negative attitudes about disability and disability discrimination in immigration is unsurprising. The conventional approach to disability is to view it as a condition to be fixed or isolated, and to view a person with a disability as equally in need of fixing or isolation. The social model of disability, an approach to disability that identifies the social, physical, and attitudinal barriers as the problem to be addressed, calls for a reexamination of the limits on immigration for people with disabilities and a discussion of how elimination of barriers would promote equality and end the subordination that people with disabilities experience.

For individuals with physical or mental disabilities, the first barrier on the road to North America is legal admission. Until quite recently, U.S. immigration law excluded thirty-three classes of immigrants, including those with intellectual disabilities, mental illness, physical defects, and various other conditions. ${ }^{7}$ Court decisions sustained exclusion on these grounds, often in cases with the flimsiest of support for the conclusion that the individual failed to meet entry standards. United States ex rel. Barlin v. Rodgers upheld the inadmissibility of three impoverished immigrants, one because he had a "rudimentary right hand," a second because he was of "poor appearance" and stuttered, and a third because he was "undersized." 8 United States ex rel. Canfora $v$. Williams determined that having an amputated leg justified exclusion of a 60year-old man, even though the man's grown children were willing to support him. ${ }^{9}$

Historically, application of the public charge exclusion-one of the most frequently usedentailed massive exercise of unreviewable discretion with regard to proof of unfitness. Immigration inspectors picked people out of line at Ellis Island if they appeared to the inspector as disabled or diseased. ${ }^{10}$ Moreover, carrier lines were forced to transport immigrants back to the

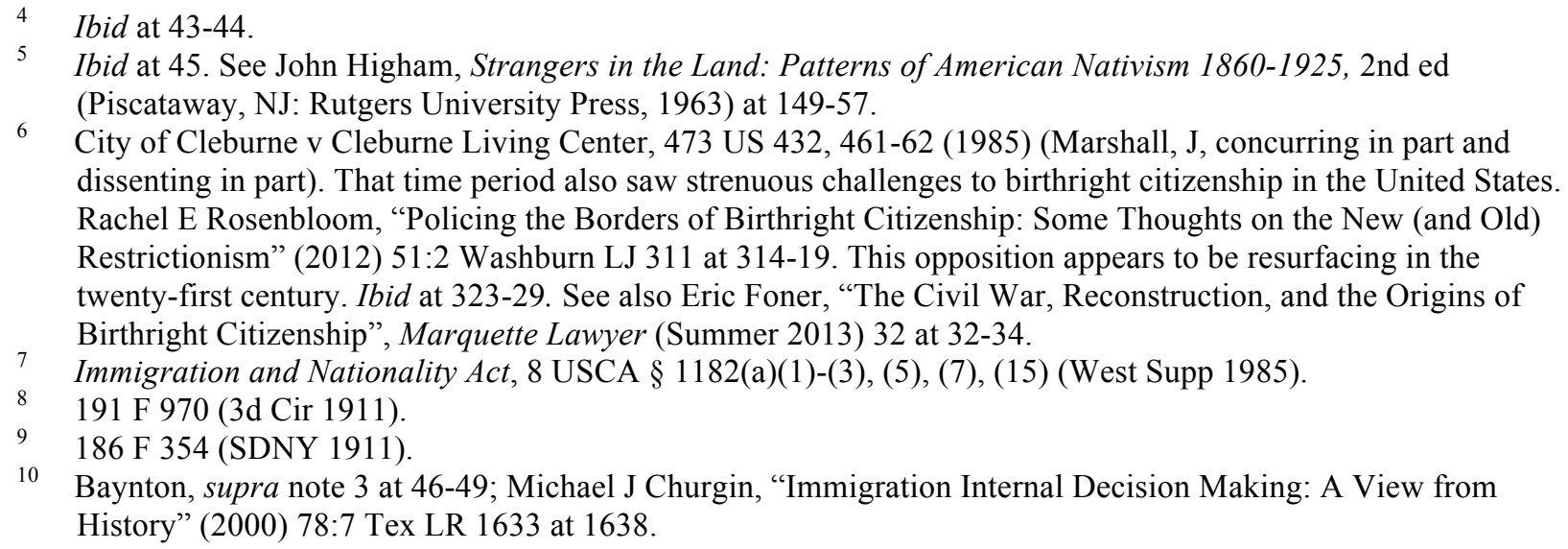


port of embarkation if the immigrants were denied entry, so steamship companies refused passage to the United States to those who looked disabled to them. ${ }^{11}$ Countries with seaports would also refuse entry to would-be emigrants seeking passage to points of embarkation if they seemed to their inspectors likely to be rejected on ground of disability by the carriers or by the United States. ${ }^{12}$

Like the United States, Canada historically excluded categories of immigrants with disabilities, who were referred to informally as the defective class and included people who were deaf, unable to speak, mentally ill, intellectually disabled, and physically ill. Canadian legislation on the topic from 1869 mirrored provincial and colonial enactments dating from as early as $1848 .{ }^{13}$ Under the provincial legislation, agents of the Chief Officer or Collector of the Port of Montreal had to identify all arriving passengers with the listed conditions and report those who appeared likely to become public charges, who could then be excluded; federal agents took over the responsibilities when the 1869 legislation came into effect. ${ }^{14}$ The exclusion was not absolute, and if family members could support the individual with a disability, entry could be allowed. ${ }^{15}$ Later legislation increased the categories of people who could be excluded, though self-support or support from family could permit entry notwithstanding the conditions. Perhaps reflecting Eugenics ideas, ${ }^{16}$ a revision in 1910 made persons with mental impairments inadmissible but allowed admission of those with physical disabilities who had family or self-support. ${ }^{17}$ Provisions excluding those with disabilities who were liable to become public charges appeared in the 1947 Act Respecting Citizenship, Nationality, Naturalization, and the Status of Aliens, the first immigration law passed by Canada itself rather than enacted subject to approval by Parliament in Great Britain, ${ }^{18}$ and in revised legislation in $1952 .{ }^{19}$

\section{PARTIAL ELIMINATION OF DISABILITY-RELATED GROUNDS FOR EXCLUSION AND CONTINUING BARRIERS TO IMMIGRATION}

Amendments to the U.S. immigration laws in 1986 permitted legalization for severely disabled undocumented immigrants already in the country, and in 1990 the United States abolished most restrictions from entry for immigrants with specific conditions such as

11 Mark C Weber, "Opening the Golden Door: Disability and the Law of Immigration” (2004) 8:1 J Gender, Race \& Just 153 at 156 .

12 Ibid at 156-57.

13 Roy Hanes, "None Is Still Too Many: An Historical Exploration of Canadian Immigration Legislation as it Pertains to People with Disabilities", online: (2009) 37:1-2 Developmental Disabilities Bulletin at 96-97, $<$ http://www.ccdonline.ca/en/socialpolicy/access-inclusion/none-still-too-many $>$.

14 Ibid at 98-99 (discussing SC 1869, c 10).

15 Ibid at 99.

16 A history of the Eugenics movement in Canada from the early twentieth century forward is contained in the expert witness report attached as Appendix A to the opinion in Muir v Alberta, 1996 CanLII 7287, 132 DLR (4th) 695 .

17 Immigration Act, SC 1910, c 27.

18 SC 1947, c 15.

19 An Act Respecting Immigration, SC 1952 c 42; Hanes, supra note 13 at 106-10. 
intellectual disabilities, mental illness, and others mentioned above. ${ }^{20}$ Restriction on entry on the basis of HIV infection was removed under a law effective January, 2010. ${ }^{21}$ Nevertheless, waivable grounds for inadmissibility to the United States still exist for individuals with specified communicable diseases; those with a physical or mental disorder and behaviour associated with the disorder that may pose a threat to property, safety, or welfare of the immigrant or others; and those likely to become a public charge. ${ }^{22}$ The public charge exclusion remains a basis of both inadmissibility and removal. ${ }^{23}$

In 1976, Canada removed outdated and offensive terms such as "mental defectives, idiots, imbeciles and lunatics" from its immigration statutes; at the same time it retained the rule of exclusion for people with disabilities who either are dangerous or could be expected to place excessive demands on health or social services. ${ }^{24}$ The excessive-demand provision parallels the likely-public-charge provision in U.S. law. One might speculate that concerns over public services expenditures may be even greater in Canada than in the United States. Authorities comparing the two countries' social safety nets recognize that Canada affords greater government support to impoverished persons. ${ }^{25}$ Professor Hanes reports that the excessive demand clause is the dominant mechanism for keeping people with disabilities from emigrating to Canada. ${ }^{26}$ Recent accounts of exclusion include those of a family with a child with a disability who emigrated to Montreal, whose application to immigrate was denied because the government spent $\$ 5,259$ per year on the child's education, ${ }^{27}$ and a father in Hamilton whose permanent residency was placed in doubt merely because his twelve year old son with autism was thought to be at risk of eventually placing excessive demand on social services. ${ }^{28}$

20 See the text accompanying notes 7-9. For a more complete discussion of the changes in the law, see Weber, supra note 11 at 162-163.

21 Tom Lantos and Henry J Hyde United States Global Leadership Against HIV/AIDS, Tuberculosis, and Malaria Reauthorization Act of 2008, Pub L No 110-293 § 305, 122 Stat 2918 (2008) (codified at 8 USC $\S$ 1182(a)(1)(A)(i)).

22 Inadmissible Aliens, 8 USC § 1182(a)(1)(A)(i)-(iii), (a)(4), 1227(a)(5).

23 Ibid at $\S 1182(\mathrm{a})(4), 1227(\mathrm{a})(5)$.

24 Hanes, supra note 13 (discussing Immigration Act, SC 1976, c 52). The current provision reads: "38(1) Health grounds. A foreign national is inadmissible on health grounds if their health condition (a) is likely to be a danger to public health; (b) is likely to be a danger to public safety; or (c) might reasonably be expected to cause excessive demand on health or social services." Immigration and Refugee Protection Act, SC 2001, c 27, s 38(1). The statutory language does not include specific disabling conditions. Under current law, the provision does not apply to an individual (1) who is determined to be a member of the family class and is the spouse, common-law partner, or the child of a sponsor, (2) who has applied for a permanent resident visa as a refugee, (3) who is a protected person, or (4) who, according to regulations, is the spouse, common-law partner, child or other family member of a person in one of the other three categories. Ibid, s 38(2).

25 Michael Wiseman \& Martynas Ycas, "The Canadian Safety Net for the Elderly" (2008) 68:2 Social Security Bulletin 53 at 61 .

26 Hanes, supra note 13 at 117-18.

27 Council of Canadians with Disabilities, "CCD Dismayed Family with a Disabled Child Ordered Deported" (13 April 2011), online: Council of Canadians with Disabilities $<$ http://www.ccdonline.ca/en/socialpolicy/accessinclusion/press-release-immigration-13april2011>.

28 Council of Canadians with Disabilities, "Immigration and Disability" (23 April 2012), online: Council of Canadians with Disabilities $<$ http://www.ccdonline.ca/en/socialpolicy/immigration/immigration-and-disabiity- 
In Hilewitz v Canada (Minister of Citizenship \& Immigration), the Supreme Court of Canada mitigated the impact of the exclusion by ruling that "medical officers must assess likely demands on social services, not mere eligibility for them," and they must consider "the willingness and ability of the applicant or his or her family to pay for the services," making "individualized assessments" rather than a mere classification of the impairment. ${ }^{29}$ Medical officers need to evaluate factors that are both medical and non-medical, including "the availability, scarcity or cost of publicly funded services, along with the willingness and ability of the applicant or his or her family to pay for the services." ${ }^{, 30}$ The court overturned the exclusion of two families that included children with intellectual disabilities when the families had private means and insisted that they would provide for the children without public social services support. ${ }^{31}$ The fear that the families might fall back on public support if hard times occurred was dismissed as speculation. ${ }^{32}$ From a disability rights perspective, treating the immigrant on an individualized basis and not as merely the manifestation of a disabling condition is surely a welcome development, though it may be noted that the interpretation of the law perpetuates a discrimination based on wealth. ${ }^{33}$

In fiscal year [FY] 2013, 240 would-be immigrants to the United States were denied visas due to physical or mental disorders, although 84 overcame findings of ineligibility on that ground. The denial and overcoming-of-denial numbers are not fully comparable, because visa applicants who overcome findings of ineligibility in a given year may have been denied visas in the previous year or years. The public charge exclusion led to 3,544 immigrant visa denials in FY

23March2012>. Professor Capurri has recounted the story of her own exclusion on excessive demand grounds due to disability. Valentina Capurri, Canadian Public Discourse around Issues of Inadmissibility for Potential Immigrants with Diseases and/or Disabilities 1902-2002 (PhD Thesis, York University Graduate Program in History 2010) [unpublished] (on file with author) at 5-11 [Capurri, Discourse]. The thesis contains analysis of 17 Canadian court cases from 1988-2005 dealing with exclusion based on excessive demand because of disability. Ibid at 302-48. Exclusions of the public charge or excessive demand type are hardly unique to North America, and may in fact be harsher in other places. See Timothy P Fadgen \& Guy Charlton, "Humanitarian Concerns and Deportation Orders under the Immigration Act 2009: Are International Obligations Enough Protection for the Immigrant with Mental Illness?" (2012) 43:3 VUWLR 423 at 427 (New Zealand); Helen Meekosha \& Leanne Dowse, "Enabling Citizenship: Gender, Disability and Citizenship in Australia" (1997) 57:1 Feminist Review 49 at 54, 64; Michael Williams, "Murky Waters: Inquiry into the Migration Treatment of Disability” (2010) 8:1 HIV Australia 7. See also Sagit Mor, “'Tell My Sister to Come and Get Me Out of Here' - A Reading of Ableism and Orientalism in Israel's Immigration Policy (The First Decade)" (2007) 27:4 Disability Studies Q 14 (discussing application of public health exception to right to immigrate to Israel).

292005 SCC 57 at paras 54-56, [2005] 2 SCR 706 (emphasis in original). The court's focus on excessive demand for social rather than medical services in the cases being considered might diminish the applicability of the decision. See ibid at para 62.

30 Ibid at para 55. Further explanation of the intended operation of the excessive demand provision is found ibid at paras 51-56.

31 Ibid at para 70.

32 Ibid at para 68.

33 See Capurri, Discourse supra note 28 at 329 ("[Hilewitz] validates the distinction among people on the basis of financial means and economic potential, while ignoring all other noneconomic contributions an individual has to make."). 
2013, though 3,374 people overcame the finding during the same period. ${ }^{34}$ The number of visas denied on public charge grounds ranges considerably from year to year. A total of 10,869 immigrants had visa applications denied on public charge grounds in FY 2010; 7,516 people overcame the finding that year. ${ }^{35}$

Vast discretion remains with regard to immigrant visa ineligibility determinations and waivers, since U.S. consular officials abroad make these determinations on their own, ${ }^{36}$ as do their counterparts administering Canadian immigration law. ${ }^{37}$ With regard to public charge denials, the officers in U.S. consulates are supposed to consider age, health, family status, assets, resources and financial status, and education and skills, as well as affidavits of support by relatives or others. ${ }^{38}$

\section{EMERGING ISSUES IN IMMIGRATION AND DISABILITY}

In Canada and the United States, recent developments pertaining to immigration in general have a specific bearing on disability rights. In Canada, there is a double edge to the application of humanitarian and compassionate grounds for permitting immigrants to stay in the country when disability comes into play. In the United States, the difficulties faced by individuals in immigration detention who lack representatives are compounded for those with mental disabilities.

\section{A. Hardship Related to Disability as a Basis for Staying Removal from Canada}

When an immigrant is threatened with deportation from Canada for reasons such as violation of the criminal law, hardship related to disability constitutes a basis that the Immigration Appeal Division of the Immigration and Refugee Board may consider in deciding to stay the order. ${ }^{39}$

34 Bureau of Consular Affairs, US Department of State, Report of the Visa Office 2013 (Washington, DC:

Government Printing Office: 2013) at Table XX. As with the visa denials due to physical and mental disorders, the numbers of visas denied and overcome are not fully comparable because the denials may have been in previous years.

35 Bureau of Consular Affairs, US Department of State, Report of the Visa Office 2010 (Washington, DC: Government Printing Office: 2010) at Table XX.

36 See The Immigrant Visa Process, online: US Department of State Bureau of Consular Affairs, $<\mathrm{http} / /$ travel.state.gov/content/visas/english/immigrate/immigrant-process.html $>$.

37 George Jordan Ashkar, Note, "Oh Canada! We Stand on Guard for Thee: Bill C-50 and the Negative Impact It 'May' Have on Immigrant Hopes, Immigrant Objectivity, and the Refugee Protection Act of 2002" (2011) 17:1 Southwestern J Intl L 143 at 160. Courts do overturn visa officer determinations in some instances. See e.g. Perez v Canada (Minster of Citizenship \& Immigration, 2011 FC 1336, 209 ACWS (3d) 408.

38 US Citizenship \& Immigration Services, Public Charge, online: US Citizenship \& Immigration Services $<$ http://www.uscis.gov/green-card/green-card-processes-and-procedures/public-charge $>$. Other countries also afford their officials wide latitude in determining whether to refuse visas to immigrants who might not be able to support themselves. International Organization for Migration, Comparative Study of the Laws in the 27 EU Member States for Legal Immigration (Feb 2008), online: European Parliament $<$ https://ec.europa.eu/migrantintegration/index.cfm-?action=furl.go\&go=/library-doc/comparative-study-of-thelaws-in-the-27-eu-member-states-for-legal-immigration> at 33-34.

39 Canada (Minister of Citizen and Immigration) v Markovska, 2013 FC 819, 19 Imm LR (4th) 32 at para 13. Grounds for a stay include: "The seriousness of the offence(s) leading to the removal order; The possibility of 
Thus in Canada (Minister of Citizenship and Immigration) v Markovska, the Federal Court affirmed a decision to stay deportation of an individual who had been convicted of criminal fraud, taking into account the immigrant's disability and the fact that she was the sister of a permanent resident; although the immigrant subsisted on disability benefits due to a workplace accident, the dependency on the benefits was not cited as a consideration against her. ${ }^{40}$

Disability may also be a basis for an exemption from the general requirement to apply for a permanent resident visa from outside Canada's borders. In Bailey $v$ Canada (Minister of Citizenship and Immigration), the Federal Court overturned the denial of the application for exemption from the requirement, on humanitarian and compassionate grounds, of a 60-year-old Jamaican with quadriplegia, who contended that no facilities existed in Jamaica to provide the 24-hour care and assistance, including feeding and hygiene, that he needed to survive. ${ }^{41} \mathrm{He}$ had become paralyzed because of a beating after he informed on drug dealers while in Ontario and had no use of his limbs apart from some movement of his upper arms. ${ }^{42}$ The Immigration officer reviewing his application found him disqualified due to criminal activity he engaged in while he was living in the United States. ${ }^{43}$ The court reasoned that the officer ignored clear evidence that no facilities were available in Jamaica to serve someone of the applicant's age with the degree of disability the applicant had. ${ }^{44}$ The court stressed that the applicant was extremely vulnerable, lacked family and other support in Jamaica and could face death on the streets there. ${ }^{45}$ Although the Federal Court decision emphasized the medical needs and humanitarian and compassionate grounds for quashing the officer's decision, it mentioned evidence of widespread disability discrimination in Jamaica and lack of evidence of any activity to implement the Convention on the Rights of Persons with Disabilities in that country. ${ }^{46}$

The holdings do not always support the disabled immigrant, however. In a 2012 case, a court rejected a challenge to removal brought by a person with paranoid schizophrenia who had been a permanent resident of Canada since 1984 but lost permanent resident status in 2011 due to

rehabilitation and the risk of re-offending; The length of time spent in Canada and the degree to which the appellant is established here; The family in Canada and the dislocation to the family that a removal would cause; The degree of hardship that would be caused to the family by the appellant's return to her country of nationality; The support available to the appellant within the family and the community; The degree of hardship that would be caused to the appellant by her return to her country of nationality." Ibid. In addition, humanitarian and compassionate grounds permit an individual to become a permanent resident of Canada even though the immigrant would otherwise not be eligible for that status. Government of Canada, "Humanitarian and Compassionate Grounds,", online: Government of Canada <http://www.cic.gc.ca/english/refu-gees/inside/hand-c.asp $>$.

$40 \quad$ Ibid at paras 2, 13.

412014 FC 315, 24 Imm LR (4th) 298 at paras 69-72.

$42 \quad$ Ibid at para 2.

43 Ibid.

44 Ibid at para 69. The decision of the officer was based largely on internet research relating to aspirations of organizations to provide services of a type different from what the applicant needed to a different population of individuals with disabilities.

45 Ibid at para 71.

46 Ibid at para 40. 
criminality. ${ }^{47}$ The court concluded that the pre-removal risk assessment would be upheld because although the immigrant might be subject to discrimination on the ground of disability if he returned to Trinidad and Tobago, there was inadequate evidence to show that he would personally face discrimination that would rise to the level of persecution. ${ }^{48}$ In another case, a court dismissed an application for judicial review of a decision rejecting an application for permanent residence on the basis of humanitarian and compassionate grounds when the evidence was that the applicant's child had a learning disability and anxiety, but it appeared that the country of the applicant's citizenship (Argentina) provided access to specialized instruction. ${ }^{49}$

However welcome the prospect of relief from removal may be for the immigrant with a disability, the application of the humanitarian and compassionate grounds may strike an observer as uncomfortably close to charity, or what Professor Degener has called "pity law."50 Nevertheless, in practice, it seems that courts are willing to recognize that absence of accommodations in the country of the immigrant's origin does constitute discrimination, and at the extreme, that it amounts to persecution, so a disability rights perspective is not altogether lacking.

\section{B. Risks of Erroneous Detention and Removal from the United States for Individuals with Mental Disabilities}

When an immigrant is in the United States, a disability-based removal may occur without legal justification due to administrative errors. Moreover, even a person who has permanent resident status may forfeit eligibility to stay in the United States due to minor criminal conduct that might be related to mental health problems. This conduct could include shoplifting, drug use, and trespassing - activities that an individual may be prone to do upon failing to take medications $^{51}$ or falling into crisis for other reasons. ${ }^{52}$ Moreover, mental or other disabilities bring to the attention of the immigration authorities persons with uncertain legal status who might otherwise pass unnoticed.

Some immigrants have valid claims to remain in the United States but have trouble asserting them due to mental incapacity, or they waive a hearing and agree to removal because they do not understand that they have strong legal grounds to remain in the United States, or because they wish to end detention and do not fully understand what removal means. ${ }^{53}$ One source estimates that $15 \%$ of persons in immigration detention have a mental disability, a number that works out

47 Louis v Canada (Minister of Citizenship and Immigration), 2012 FC 1055, 2012 CarswellNat 4208 (WL Can).

48 Ibid at paras 26-27.

49 De Vazquez v Canada (Minister of Citizenship and Immigration), 2014 FC 530 at para 35, 240 ACWS (3d) 959.

50 Theresia Degener \& Gerard Quinn, “A Survey of International, Comparative and Regional Disability Law Reform”, online: Disability Rights Education \& Defense Fund < http://dredf.org/news/publications/disabilityrights-law-and-policy/a-survey-of-international-comparative-and-regional-disability-law-reform $>$.

51 Human Rights Watch, Deportation by Default: Mental Disability, Unfair Hearings, and Indefinite Detention in the US Immigration System, (New York: Human Rights Watch, 2010) at 15.

52 Alice Clapman, "Hearing Difficult Voices: The Due-Process Rights of Mentally Disabled Individuals in Removal Proceedings" (2011) 45:2 New Eng L Rev 373 at 374.

53 Human Rights Watch, supra note 51 at 26; Jacqueline Stevens, "U.S. Government Unlawfully Detaining and Deporting US Citizens as Aliens” (2011) 18:3 Va J Soc Pol’y \& L 606 at 631-32. 
to roughly 57,000 individuals at any given time. ${ }^{54}$ If the immigrant makes it to a hearing before an immigration judge, there is no statutory right to have counsel appointed if the individual is indigent, as many detainees with mental disabilities are, and there are few accommodations in place to facilitate fair decision making when the immigrant has a mental disability. ${ }^{55}$

This state of affairs has not gone unchallenged. Franco-Gonzales $v$ Holder, a class action lawsuit filed on behalf of individuals who are or will be in custody for removal proceedings in California, Arizona, and Washington State who have been identified as having severe mental disabilities, alleged that in removal proceedings immigrants were denied competency evaluations, appointment of counsel, and prompt custody determinations, all in violation of constitutional rights and rights under the federal immigration and disability discrimination laws. ${ }^{56}$ Early in the case, the court entered a preliminary injunction for the two named plaintiffs, requiring that they be allowed a hearing with a competent and zealous representative who would be free from conflicts of interest and bound by confidentiality obligations, though not necessarily an attorney. ${ }^{57}$ Then, in 2013, the court granted partial summary judgment to the plaintiffs, ruling that denying the accommodation of a qualified representative to individuals who are not competent to represent themselves by reason of a serious mental disorder or defect violates Section 504 of the Rehabilitation Act of $1973 .^{58}$ The judge determined that the accommodation was a reasonable one, finding that the absence of a representative impeded class members' meaningful access to the courts. ${ }^{59}$ Moreover, because representation could be provided by qualified non-attorneys, the burden on the government was not severe enough to cause a fundamental alteration of the government's program. ${ }^{60}$ The court entered a permanent injunction granting relief to the class members. ${ }^{61}$

54 Human Rights Watch, supra note 51 at 3.

55 Ibid at 42-51.

56 General information on the case is found in Aliza B Kaplan, "Disabled and Disserved: The Right to Counsel for Mentally Disabled Aliens in Removal Proceedings" (2012) 26:3 Geo Imm LJ 523 at 530. The 2013 ruling in the case is discussed in Leslie Wolf, Note "After Franco-Gonzales v Holder: The Implications of Locating a Right to Counsel under the Rehabilitation Act” (2014) 23:2 Southern California Rev L \& Social Justice 329.

57 Franco-Gonzales v Holder, 767 F Supp 2d 1034 at 1056-58 (CD Cal 2010). Other members of the class also received preliminary relief. See Franco-Gonzales v Holder, 828 F Supp 2d 1133 (CD Cal 2011).

58 Franco-Gonzales v Holder, No. CV 10-02211, 2013 WL 3674492 at 3 (CD Cal. 23 Apr. 2013). Section 504 is found at 29 USC $\S 794$. Section 504, rather than the Americans with Disabilities Act, addresses disability discrimination by agencies of the federal government (as well as federal grantees, who may or may not be covered by the ADA as well).

59 Ibid at 4-5.

60 Ibid at 5-9. The court did not grant summary judgment to the plaintiff class on their claim that the Immigration and Nationality Act and the Due Process Clause of the US Constitution mandate legal representation. Ibid at 910. The court further ruled that the Immigration and Nationality Act establishes that members of the class are entitled to a bond hearing after 180 days in detention. Ibid at 10 .

61 Ibid at 20. Under the court's decree, a qualified representative is "(1) an attorney, (2) a law student or law graduate directly supervised by a retained attorney, or (3) an accredited representative, all as defined in 8 CFR $\S$ 1292.1". Ibid at 5. A subsequent ruling affecting individuals in the three states covered by the case ordered the immigration authorities to implement specific measures with regard to mental health screening and information gathering, transmission of the mental health information to immigration judges, and the conducting of 
The Executive Office for Immigration Review issued an administrative plan in anticipation of the 2013 order of the court in Franco-Gonzales. ${ }^{62}$ Phase I of the plan covers detained immigrants throughout the country and extends to them a qualified representative if they are incompetent. ${ }^{63}$ The immigration judge is charged with making a determination of mental competence, and may conduct a hearing on the issue if necessary. ${ }^{64}$ The judge is to make a referral for a mental health examination if it is needed for the determination. ${ }^{65}$ When the immigration judge finds that the immigrant is not competent to self-represent, the Executive Office must provide a qualified legal representative. $^{66}$

Even after the administrative action by the Executive Office, little direction exists about which steps to take when an immigrant who is found not to be competent is so disabled that he or she cannot meaningfully participate in proceedings even with a representative. ${ }^{67}$ The U.S. Supreme Court has ruled that it violates due process of law to keep a criminal defendant under custody indefinitely solely because the individual is unable to stand trial due to incompetency. ${ }^{68}$ Indeterminate immigration detention of an individual who is unlikely to become competent in a reasonable time would be similarly inconsistent with the constitutional guarantee of due process of law. Moreover, the competency proceedings themselves may be difficult to navigate for an immigrant in custody, who at that point will not yet have a representative. An observer noted that under the procedure prior to issuance of the plan, claims of incompetency were difficult to sustain unless the immigrant provided documentation of mental disability, which will ordinarily be found in treatment records, but "evidence that respondents are receiving any type of mental

competency evaluations. Franco-Gonzales v Holder, No. CV 10-02211, 2014 WL 5475097 at 1 (CD Cal 29

Oct. 2014).

62 Executive Office for Immigration Review, US Dep't of Justice, "Phase I of Plan to Provide Enhanced

Procedural Protections to Unrepresented Detained Respondents with Mental Disorders", online

$<$ https://dl.dropboxusercontent.com/u/27924754/EOIR\%20Protections.pdf $>$.

63 Ibid at 1.

64 Ibid at 6.

65 Ibid at $7-15$.

66 Ibid at 15.

67 See Wolf, supra note 56 at 342 . Wolf points out that if the immigrant is under detention, a finding of incompetency stops removal proceedings but does nothing to end the detention. Ibid. A recent decision may ameliorate the situation somewhat by stating that in asylum proceedings an immigrant with mental illness or a cognitive disability is not to be disbelieved simply because the immigrant's testimony is implausible or inconsistent. In re J-R-R-A-, 26 I \& N Dec 609 at 611-12 (2015) ("A situation could arise in which an applicant who is deemed incompetent by the Immigration Judge sincerely believes his account of events, although they are highly implausible to an outside observer. Alternatively, the individual could be deemed competent for purposes of his hearing, although he has been diagnosed with a mental illness or serious cognitive disability and may exhibit symptoms that affect his ability to provide testimony in a coherent, linear manner... In such circumstances, the factors that would otherwise point to a lack of honesty in a witness-including inconsistencies, implausibility, inaccuracy of details, inappropriate demeanor, and nonresponsiveness-may be reflective of a mental illness or disability, rather than an attempt to deceive the Immigration Judge. . . . Such scenarios need to be assessed on a case-by-case basis, but where a mental health concern may be affecting the reliability of the applicant's testimony, the Immigration Judge should, as a safeguard, generally accept that the applicant believes what he has presented, even though his account may not be believable to others or otherwise sufficient to support the claim.")

Jackson v Indiana, 406 US 715 (1972). 
health treatment has been treated by the BIA [Board of Immigration Appeals] as automatic evidence of their competence." 69

A recent decision of the U.S. Board of Immigration Appeals establishes a legal test for an immigrant's competency: "whether he or she has a rational and factual understanding of the nature and object of the proceedings, can consult with the attorney or representative if there is one, and has a reasonable opportunity to examine and present evidence and cross-examine witnesses." 70 The opinion further states that if there are indications of incompetency, the immigration judge must determine whether the respondent at hearing is competent, and if so, apply safeguards and articulate the rationale for the competency decision. ${ }^{71}$ But the procedures and safeguards provided fall short of what several legal authorities contend should be required by the Constitution's guarantee of due process of law when liberty to remain in the United States is at stake; these writers argue instead for safeguards that resemble those provided to persons who may be incompetent in criminal proceedings, such as an entitlement to appointed counsel or at least a highly qualified non-attorney representative. ${ }^{72}$ The interests at stake justify a high level of procedural protection. Indeed, the harms of being sent away from the United States can be so enormous and the pressure to cut corners so severe in immigration cases that Immigration Judge Dana L. Marks described asylum proceedings as "like holding death penalty cases in traffic court., 73

United States citizens and others with unquestionably valid legal grounds to remain have been taken into custody and removed from the country because of mistaken identity or other errors that they could not correct because of lack of accommodations for their intellectual disability or mental illness. Human Rights Watch reports:

In 2000, Sharon McKnight, a US citizen with cognitive disabilities, was arrested by immigration authorities returning to New York after visiting her family in Jamaica and deported through expedited removal procedures when immigration authorities suspected her passport was fraudulent. In May 2007, Pedro Guzman, a 29 year old US citizen with developmental disabilities, was apprehended by ICE [Immigration Control and Enforcement] at a county jail in California where he was serving a sentence for trespassing and deported to Mexico. Guzman was lost in Mexico for almost three months before he was found and able to return to his family in California. In December 2008, US citizen Mark Lyttle, diagnosed with bipolar disorder and developmental disabilities, was deported to Mexico (and from there to Honduras and then Guatemala.) It took four months for Lyttle to

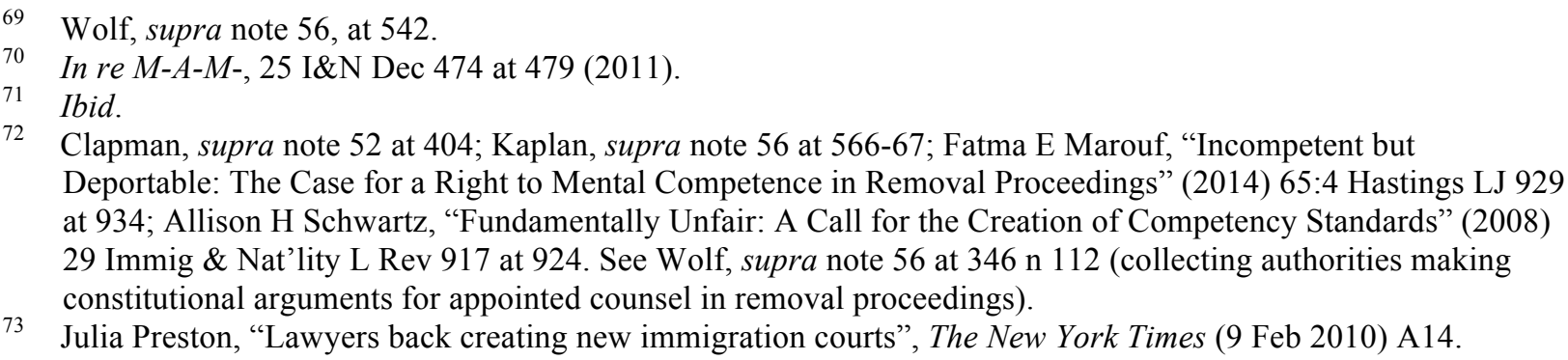


return to the US; ICE officials maintain that Lyttle signed a statement indicating he was a Mexican national. ${ }^{74}$

Additional cases are described by Professor Stevens, who states that in 2010 over 4,000 citizens were detained or deported as aliens. ${ }^{75}$ Stevens further notes that wrongful deportations and exclusions of this type have occurred with frequency for seventy-five years or more. ${ }^{76}$ Existing procedures rely on seemingly voluntary consent to removal from the United States ${ }^{77}$ and afford little or no review of low-level decision making. ${ }^{78}$ Detention itself increases the risk of error, because individuals with mental impairments may be denied access to medication and mental health services that would enable them to cope better with the challenge of presenting their case for remaining in the United States. ${ }^{79}$ Detainees are often reluctant to reveal their mental impairments and ask for help because they fear quite rationally that the impairments might be used as a ground for exclusion. ${ }^{80}$

Despite the record of difficulties and the ongoing problems, the new policy of appointing qualified representatives for incompetent immigrants who are in detention constitutes an important accommodation that diminishes the disability discrimination that immigrants would otherwise face.

\section{CITIZENSHIP FOR IMMIGRANTS WITH DISABILITIES}

The previous sections of this article described the liberalization of the underlying law with respect to entry to and remaining in the United States and Canada, while noting that procedural hurdles, evidentiary problems, and failure to accommodate make the implementation of the reform incomplete. Liberalization of the underlying U.S. law has occurred with regard to naturalization requirements as well. In the United States, naturalization is now permitted without showing English proficiency, knowledge of U.S. history and civics, ${ }^{81}$ or taking the citizen oath ${ }^{82}$

74 Human Rights Watch, supra note 51 at 27 (footnotes omitted). Lyttle's case is discussed in William Finnegan, "The Deportation Machine", The New Yorker (29 April 2013) 24.

75 Stevens, supra note 53 at 608.

76 Ibid at 638-46.

77 Human Rights Watch, supra note 51 at 50. If a person makes it to a hearing, there is at least some protection from potentially erroneous voluntarism. Immigration judges are forbidden from accepting an admission of removability from someone who is not mentally competent, unless that person is accompanied by a representative or friend, near relative, guardian, or officer of an institution at which the person is an inmate or patient. $8 \mathrm{CFR} \S 1240.10(\mathrm{c})$. It appears that an immigration official who is custodian could fill that role. Wolf, supra note 56 at 341 .

78 Stevens, supra note 53 at 652-54.

79 Kaplan, supra note 56 at 535.

$80 \quad$ Ibid at 537; Wolf, supra note 56 at 339.

81 Expanding Waiver of the Grovemment Knowledge, United States History, and English Language Requirements for Naturalization, Pub L No 103-416 § 108, 108 Stat 4305 (1994) (codified at 8 USC $\S 1423(b)(1)$ ).

82 An Act to Amend the Immigration and Nationality Act to Provide a Waiver of the Oath of Renunciation and Allegiance for Naturalization of Aliens Having Certain Disabilities, Pub L No 106-448 § 1, 114 Stat 1939 (2000) (codified at 8 USC $\S 1448(a)$ ). 
for people who cannot do so because of physical or developmental disabilities. In addition, an individual whose serious and permanent disability prevents the appearance at a citizenship ceremony may be given the oath elsewhere. ${ }^{83}$ These changes fit with the gradual acceptance of Americans with disabilities as full members of the polity. It appears that if Americans are willing to have immigrants with disabilities in their midst in the numbers and types they currently accept, they are willing to admit them to citizenship on equal terms with others. This development is unmistakably positive from the perspective of disability rights.

Under recent legislation, ${ }^{84}$ Canadian citizenship has, in general, become harder to obtain, and the changes may have a negative impact on some individuals with disabilities. Previously, applicants for citizenship aged 18 to 54 had to meet the standard of competence in English or French, and they could demonstrate their knowledge about Canada with the assistance of an interpreter. Now the language requirement applies to persons aged 14 to 64, and the knowledge requirement has to be met in English or French without an interpreter's help. ${ }^{85}$ However, the immigration authorities will accept evidence of a cognitive, psychiatric, or psychological disorder or disability that prevents the applicant from submitting proof of language ability with the application. ${ }^{86}$ Discretionary grants of citizenship are also possible when ordinary tests for citizenship are not met. ${ }^{87}$

\section{CONCLUSION: EVALUATION AND PROSPECTS FOR REFORM}

What liberalization has taken place in immigration law with respect to disability-based exclusions may be attributed to a disenchantment with Eugenics ideas after the horrors of the Nazi era, and a gradual decline in society's fear of disability. ${ }^{88}$ The movement for disability rights, which gained prominence in North America from the 1960s forward, has stressed integration and full participation in daily life for people with disabilities. ${ }^{89}$ The idea is nothing

83 An Act to Amend the Immigration and Nationality Act to Change the Level, and Preference System for Admission, of Immigrants to the United States, and to provide for administrative naturalization, and for other purposes, Pub L No 101-649 § 407(d)(12)(F), 104 Stat 4978 (1990) (codified at 8 USC $\S 1445(\mathrm{e})$ ).

84

An Act to Amend the Citizenship Act and to make Consequential Amendments to Other Acts, SC 2014, c 22.

85 Government of Canada, "Strengthening Canadian Citizenship Act: A Comparative Before and After View of the Changes to the Citizenship Act", online: Government of Canada <http://news.gc.ca/web/articleen.do?mthd=index\&crtr.page $=1 \&$ nid $=863489>$.

86 Government of Canada, "Application for Canadian Citizenship under Subsection 5(1) - Adults 18 Years of Age and Older (CIT 0002)", online: Government of Canada <http://www.cic.gc.ca/english/information/applications/guides/CIT0002ETOC.asp>.

87 Government of Canada, "Strengthening Canadian Citizenship Act: Blueprint for Citizenship Improvements", online: Government of Canada $<$ http://news.gc.ca/web/articleen.do?mthd=tp\&crtr.page=1\&nid=8632$69 \&$ crtr.tp1D $=930>$.

88 Weber, supra note 11 at 165-66. See Capurri, Discourse supra note 28 at 351 ("Whereas concerns about individuals with physical or mental 'disorders' were initially related to their economic as well as social and moral impact, the emphasis has now been restricted to the economic aspect. Today, people with a disease, disorder or disability are not excluded because they bring the threat of 'race degeneration' but because they might constitute a burden to the taxpayer.").

89 Joseph Shapiro, No Pity: People with Disabilities Forging a New Civil Rights Movement (New York: Times Books, 1993). 
less than a redefinition of the normal to include disability, and a shift in focus to eliminating barriers to integration and full opportunity. ${ }^{90}$ There has been a recognition, most strikingly in the U.S. Americans with Disabilities Act ${ }^{91}$ and in the Canadian Charter of Rights and Freedoms and statutory enactments, ${ }^{92}$ that people with disabilities belong in the national community and contribute socially, culturally, and economically to the commonwealth, and that accommodations ought to be provided to facilitate belonging and contribution.

Moreover, in America the Immigration Act of $1990^{93}$ completed a reorientation of the U.S. immigration system from a single-minded focus on labour needs towards family unification concerns. Hence, immigrants' inability to work due to unaccommodated disability is less important, at least as long as it does not result in a need for public support. Mixing a metaphor yet stating matters accurately, one source declares that "The cornerstone of the current system revolves around family reunification." 94 This situation contrasts sharply with an immigration policy closely tied to the need for labour, ${ }^{95}$ although the economy's labour needs remain a significant theme in immigration regulation in the United States and are a particularly prominent theme in Canada. One source comments: "Distaste for racial or national-origin restrictions finally provoked policy change in both countries in the 1960s, but with strikingly different results. The United States chose family reunification as the major goal of admissions policy; Canadian governments promoted permanent immigration as a path to economic growth." 96

90 Harlan Hahn, "Equality and the Environment: The Interpretation of 'Reasonable Accommodations' in the Americans with Disabilities Act" (1993) 17:3 J of Rehabilitation Administration 101.

9142 USC $\S \S 12101-12213$.

92 Canadian Charter of Rights and Freedoms, s 15, Part I of the Constitution Act 1982, being Schedule B to the Canada Act 1982 (UK), 1982, c 11. See, e.g. Accessibility for Ontarians with Disabilities Act, SO 2005, c 11; Accessibility for Manitobans Act, SM 2013, c 40. The organized disability community pressed hard to have disability included in section 15 of the Charter, over the initial opposition of the federal government - see e.g. Sarah Armstrong, "Disability Advocacy in the Charter Era" (2003) 2:1 JL \& Equality 33 and Yvonne Peters, "Twenty Years of Litigating for Disability Equality Rights: Has it Made a Difference? An Assessment by the Council of Canadians with Disabilities" (26 January 2004), online: Council of Canadians with Disabilities $<$ http://www.ccdonline.ca/en/humanrights/promoting/20years\&sa=U\&ei=WE1YU_XyCIyA2QX8tYGgDg\&ve

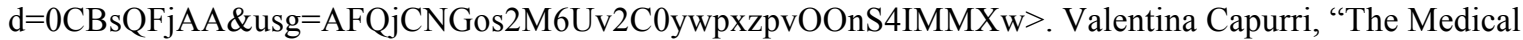
Admissibility Provision vis-à-vis the Charter of Rights and Freedoms” (2012) 16:1 Left History 91. Professor Capurri notes that the removal of immigrants on disability-related grounds may be contested under the Charter but that litigants appear unwilling to make the argument, perhaps because of fear it would not succeed; it has not so far prevailed. See Chesters $v$ Canada (Minister of Citizenship and Immigration), [2003] 1 FC 361,115 ACWS (3d) 603 (denying immigrant's Charter-based challenge to her inadmissibility on medical grounds).

93 Supra note 83.

94 Nicole Green \& Ann Chih Lin, Immigration (Washington, DC: Congressional Quarterly Press, 2002 ) at 22.

95 Higham, supra note 5 at 114.

96 Irene Bloemraad \& Doris Marie Provine, "Immigrants and Civil Rights in Cross-National Perspective" (2013) 1:1 J Comparative Migration Studies 45 at 53. Regarding Canadian immigration policy and labour needs, see Ashkar, supra note 37 at 146-47. Professor Capurri believes that the Canadian immigration system is "predicated on the belief that individuals are worthy only insofar as productive and useful to the material growth of the country," and that immigrants with disabilities are thought of as "the prototype of unproductiveness and un-usefulness." She states that "The focus on productivity as one of the prerequisites in the decisions made to guarantee the well-being of the country is what has allowed the Canadian state to maintain 
The public charge and excessive demand restrictions remain a significant discriminatory barrier to entry, and in the United States great problems continue with the evidentiary and procedural aspects of the administration of the immigration laws in general, as well as the difficulty in navigating the immigration system for individuals with mental illness or intellectual disabilities. Relaxation of public charge-related exclusions and adoption of reforms such as more widely available examinations for incompetency and broader access to lawyers for indigent persons subject to removal would go far to accommodate people with disabilities striving to obtain the benefit of the recent changes in the immigration laws.

More specifically, in the United States the reforms occasioned by the Franco-Gonzales case represent an important instance of accommodation for immigrants with disabilities, but the reforms remain at this time a matter of court order in three states and an ad hoc administrative edict elsewhere. In 2014, Representative Jeffries introduced a bill to provide counsel for unaccompanied immigrant children and people with mental disabilities in removal proceedings. ${ }^{97}$ Adoption of this statutory change would make the accommodation secure. In addition, as noted above, having representation at the competency hearings themselves is a needed accommodation. Consent to removal should not be solicited or accepted from those who do not fully understand what they are signing. And those individuals who are unlikely ever to become competent must not be held indefinitely, in accordance with well established United States Supreme Court caselaw interpreting the due process clause.

In Canada, and perhaps someday in the United States, advocates should be able to support their case for reforms with Article 18 of the United Nations Convention on the Rights of Persons with Disabilities. ${ }^{98}$ The Convention mandates both freedom of movement across borders on a nondiscriminatory basis and accommodations in the immigration process. It provides that "States Parties shall recognize the rights of persons with disabilities to liberty of movement, to freedom to choose their residence and to a nationality, on an equal basis with others," and that states parties must ensure that persons with disabilities "[a]re not deprived, on the basis of disability, of their ability to obtain, possess and utilize documentation of their nationality or other documentation of identification, or to utilize relevant processes such as immigration proceedings, that may be needed to facilitate exercise of the right to liberty of movement. ${ }^{, 99}$ To the extent that considerations of public charge and excessive demand correlate with disability, compliance with the Convention would call for reasonable modifications of those exclusionary provisions. At the minimum, the obstacles faced by people with disabilities in U.S. immigration proceedings will need to be addressed if the United States ratifies the Convention and enacts legislation to put it into effect. ${ }^{100}$

the medical inadmissibility provision despite its apparent unconstitutionality." Capurri, Discourse, supra note 28 at $16-17$.

97 Vulnerable Immigrant Voice Act, HR 4936, 113d Cong (2014) (not adopted). See online: Congress.gov

$<$ https://www.congress.gov/bill/113th-congress/house-bill/4936/text>.

98 GA Res 61/106, (2007).

$99 \quad$ Ibid art $18 \mathrm{~s} 1$.

100 For a further discussion of potential impact of the Convention on US policy, see John R Vaughn, "Finding the Gaps: A Comparative Analysis of Disabilities Law in the US to the UN Convention on the Rights of Persons 
Finally, at least in the United States, involvement in the criminal justice system is a broad gateway to removal of immigrants with disabilities. In the absence of adequate mental health services ${ }^{101}$ and the presence of criminalization of behaviours such as sleeping in parks or public transit, begging in prohibited areas, and possession of small amounts of drugs, ${ }^{102}$ persons with mental illness will continue to be swept off the street and into immigration detention. Provision of mental health services and decriminalization of conduct that is essentially harmless, even if sometimes disturbing to outsiders, is a change that would effectively produce an accommodation for the life challenges of persons with mental disabilities in the contemporary North American environment.

The recent reforms in United States practices regarding naturalization are a valuable accommodation for immigrants with disabilities yearning for citizenship. These reforms are worthy of consideration in Canada. At the minimum, Canadian lawmakers might reconsider the recent changes that have made attaining citizenship more difficult for persons with disabilities. The relaxation of some disability-related immigration restrictions in the United States and Canada and easing of the required showings for U.S. citizenship illustrate the significant, though incomplete, removal of disability-related barriers in North American law and society.

with Disabilities" (12 May 2008), online: National Council on Disability < http://www.ncd.gov/publications/2008/May122008\#a18>.

101 See Michelle Wilde Anderson, "The Western, Rural Rustbelt: Learning from Local Fiscal Crisis in Oregon" (2014) 50:4 Willamette L Rev 465 at 479-80.

102 See Paul D Butler, "Poor People Lose: Gideon and the Critique of Rights" (2013) 122:8 Yale LJ 2176 at 2183 85 (collecting sources). 